\title{
Contribution of Export Processing Zone for Regional Development: With Special Reference to Biyagama Export Processing Zone
}

Sri Lanka Journal of Social Sciences and Humanities Volume 1 Issue 2, August 2021: 13-26 ISSN: 2773 692X (Online), 27736911 (Print) Copyright: (C) 2021 The Author(s)

Published by Faculty of Social Sciences and Languages, Sabaragamuwa University of Sri Lanka Website: https://www.sab.ac.lk/sljssh DOI: http://doi.org/10.4038/sljssh.v1i2.34

\author{
Wijerathna, K.B.P.C.A. ${ }^{1{ }^{*}}$ and Liyana Arachchi, L.A.V.Y.P. ${ }^{1}$ \\ ${ }^{1}$ Department of Geography \& Environmental Management, Sabaragamuwa University of Sri Lanka, Belihuloya, 70140, \\ Sri Lanka.
}

Received: 24 November, 2020, Revised: 22 February, 2021, Accepted: 06 April, 2021.

How to Cite this Article: Wijerathna, K.B.P.C.A. and Liyana Arachchi, L.A.V.Y.P. (2021). Contribution of export processing zone for regional development: with special reference to Biyagama export processing zone. Sri Lanka Journal of Social Sciences and Humanities, 2(1), 13-26.

\begin{abstract}
Export Processing Zones could be identified as a strategy used by the developing countries to minimize the adverse impacts caused by regional disparities. Biyagama Export Processing Zone (BEPZ) has been established within Biyagama Divisional Secretariat Division (DSD) to overcome the backwardness of development it had for a long period. The objective of this study is to identify the regional development impacts of BEPZ on the Biyagama DSD through the development of infrastructure and employment generation. The sample of 100 residents has been selected through simple random sampling for the questionnaire survey. Other than that, interviews and direct observation method has been utilized for primary data collecting and web sites of relevant authorities, books, and institutional reports have been used for collecting secondary data. Map analysis and Shift Share analysis have been used to identify the contribution of the zone for the regional development. Infrastructure facilities such as road networks, electricity and water supply, educational facilities, and telecommunication facilities have been developed with the establishment of the BEPZ. Living standards of the people in the area have been developed as a result of the indirect employment opportunities created after the establishment of the zone. The majority of the females are engaged in indirect employment activities. As a result, female empowerment is high within the Biyagama DSD. The contribution of the BEPZ for the generation of direct employment opportunities is also at an optimum level. The establishment of the Export Processing Zone results in the social, economic, cultural, environmental, and regional changes within the area. Hence it can be recognized as the major contributor to the development of Biyagama region.
\end{abstract}

Keywords: Communication anxiety, Cooperative learning, Second language, Teaching strategy.

\section{INTRODUCTION}

Industrialization is the process of changing the social and economic aspects of society and transforms it from an agrarian one to an industrial one. In other words, it is the process that develops the industrial sector of a country. Industrialization can help a nation to achieve economic development, poverty reduction in the country, and ultimately sustainable development. With the rapid spreading of industrialization, most of the countries achieved economic development and become powerful nations in the world. To get complied with the global economic trends most of the developing nations move away from import-oriented economies to export-oriented ones. Therefore, nations in Asia, Africa, and Latin America are designing export promoting programs to encourage foreign-based investments from multinational corporations. One of the many tools used by developing nations worldwide is Export Processing Zones (EPZ). The concept of EPZs may have originated from Free Trade Zones established in major ports like Singapore and Hong Kong. The mechanism has various names as Free Trade Zone, Industrial Zone/park, EPZ, Special Economic Zone, etc. Industrial parks are the areas that provide entrepreneurs with incentives and a barrier-free environment to stimulate economic development by attracting foreign investment to the country.
Most of the developing nations in the world have been using EPZs to encourage foreign investments since the 1930s. When considering the history of the EPZs the very first zones were found in Latin America. The United States initiated its first EPZs in 1934. When considering the distribution of processing zones, the highest number of zones could be identified in North America (320) and Asia (225). Most of the developing nations are now corresponding with the EPZs to stimulate their economic stability. Examples for some of these nations are the Caribbean with 51 zones, Central America with 41, the Middle East with 39, and these figures are increasing throughout the world by the time.

Asia can be identified as the region with the second-highest number of EPZs. There are $225 \mathrm{EPZs}$ established within the Asian region. The first Asian EPZ was established in 1965 in Kendla in India by the Indian government. Almost every developing country in Asia has EPZs established within their boundaries to enhance their economic development. Considering the experiences of other Asian countries China has had an open-door policy and established EPZs in 1979 and early 1980s. Now China alone has nearly 124 EPZs within

\footnotetext{
* Corresponding author: Tel.: +94 (71) 044 1894; Email: anuradha@ssl.sab.ac.lk

(iD) https://orcid.org/0000-0002-9924-2880
} 
their boundaries to achieve not only export-oriented industrialization as well as national development. Out of $845 \mathrm{EPZs}$ throughout the world, Asia comprises 225 which is nearly $26.62 \%$. These zones are considered to be the most successful especially the ones located in Taiwan, Hong Kong, and South Korea, Singapore which are considered as Asian tigers. They provide various facilities like duty-free tax incentives, building permits, developed infrastructure facilities, etc. to attract more and more foreign investors to their regions. At the beginning of the process of industrialization in the world, they were located in the metropolitan regions considering the available facilities. Hence, a large volume of people migrated to these metropolitan areas from the rural areas seeking job opportunities and the required resources were also extracted from these rural areas. Therefore, rural areas had to undergo exploitation. But the EPZs were established in rural areas aiming their development.

During the period of 1960s and 1970s, industrial development was at a peak for the newly developed countries of East Asia. Even though foreign trade-based investments do not play a vital role in the countries like South Korea countries like Sri Lanka need to develop export markets. Like most of the developing countries, Sri Lanka is another Asian country that has gained a lot of advantages by establishing EPZs within the country. The development of the EPZs within Sri Lanka dates back to the 1970s. Five EPZs are currently operating within the country. The first EPZ was established within the country in 1978 at Katunayake. With the advancement in the economy, more EPZs were established at Biyagama, Koggala, Mihinthale, and Pallekale. Out of these five Katunayake and Biyagama zones contribute the most for the enhancement of the economy. Both these zones can achieve economic development as well as social development. Regional development can be considered as the most important outcome of establishing EPZs in the country. According to a study, because of Wathupitiwala Export Processing Zone, Attanagalla DS Division has achieved a massive level of development in infrastructure and the living standards of the people have risen. "Infrastructure facilities such as transportation, electricity, telecommunication, banks developed via the established Wathupitiwala Export Processing Zone. Generated direct and indirect employment opportunities. Income and expenditure of the local community have changed, while their savings and investments increased in addition to the direct investments in the project" (Waniganeththi, 2008). This study is going to examine how the Biagama Export Processing Zone (BEPZ) contributes to the development of infrastructure facilities such as transportation, electricity, water, education, and telecommunication via the establishment of the BEPZ.

\section{Objectives}

The main objective of this study is to examine how BEPZ has contributed to regional development. Specific objectives of this study are to examine how the employment opportunities have been developed in the study area through the shift-share analysis,

- To understand how the road networks of the Biyagama DS Division have expanded with the establishment of BEPZ

- To understand the development of settlements in Biyagama DS Division have expanded with the establishment of BEPZ

- To examine how the supply of water and electricity has been increased within Biyagama DS Division
- To examine the availability of the education facilities within the Biyagama DS Division

\section{LITERATURE REVIEW}

Introduction to Export Processing Zones: "Industrialization is the process by which an economy is transformed from primarily to agricultural to one based on the manufacturing of goods" (http://www.investopedia.com>terms>i...., 2018). The process took place during the mid-18th to 19th century within certain parts of Europe like Great Britain, Belgium, France and Germany, and North America. The process can influence the entire world from the very beginning. Most of the developed countries undergo the process of industrialization and have now achieved a massive scale of development. As a result, they have now become the most powerful economies in the world. When considering the beginning of the industrial development within these countries almost every industrial activity was concentrated in the urban centers or the metropolitan regions. Therefore a large volume of people migrates to those areas from the rural areas seeking new employment opportunities and better standards of life. And the raw materials required for these industries were also acquired from the rural areas. As a result, rural areas of the countries had to undergo a crisis of exploitation by the industrialized areas and have backwardness in the development. By the time this became a severe problem for the rural areas because the exploitation from the industrial cities was severe. As a solution for these problems industrial parks or the EPZs came into the picture.

According to Kiselakowa et.al 2014 industrial zones could be considered as a modern concept that has been adopted by almost every country in the world to achieve economic development. "It can be considered industrial parks as one of the modern phenomena according to the frequency with which more and more business entities, cities, municipalities and regions in the world are reaching after them. With the development of the macroeconomic environment, cities have been getting gradually the discovery of industrial parks. This development is particularly influenced by structural reforms of the economy and the production spheres that are affected by ever stronger competitive struggle within the constantly changing global market space and the impacts of the global crisis" (Kiselakowa et.al, 2014). Considering the situation of most of the developing countries Kiselakowa et.al have further stated that since the rural areas are suffering from a lack of technology, good infrastructure, employment opportunities, etc. the governments could overcome these flows with the help of foreign incentives and funds. The reason is that they can increase the competition, bring in new technologies, introduce marketing strategies, etc. Therefore rather than having only local entrepreneurs to invest within the country and support the economy EPZs encourage the foreign investors and entrepreneurs to invest within the developing regions which ultimately help to achieve an evenly distributed development.

According to Eugenia et.al 2013, EPZs can be considered as a tool adopted by the regions to overcome the negative flows of the industries. Modernization and the usage of technology for the industries would lead to a diversification of industrial activities and ultimately for sustainable industrial development. But due to the imperfections in the rules and regulations of the country, market structures, etc., it may restrict the industries from accessing the information, technology, knowledge and may cause backwardness in the industrial activities. "In an attempt to accelerate the process 
of reforming the economy, the central institutions focus on supporting the use of technology to modernize the industry that would lead to the diversification of activities and the achievement of sustainable industrial development. The imperfections of the market and the institutional system hamper companies' access to information, knowledge, new technology and financing resulting in increased business risk and directly affecting the progress towards achieving development goals" (Eugenia et.al, 2013). As they further mention EPZs could be identified as a way of increasing local productiveness and competitiveness. The main aim of the EPZs is to attract foreign investments to the country. So they provide a variety of facilities like improved infrastructure, training, and technical guidance, etc. Therefore, these EPZs could be identified as the centers of growth which support the local as well as the economic development. According to their findings, EPZs can generate a convenient environment for the development of industrial-scale and local productivity. "Industrial parks can provide a favorable environment for the development of concentrated firms but also the local development" (Eugenia et.al, 2013). The development of EPZs within the countries is a very important factor considering their contribution toward economic development. Since the central institutions support the industrial zones with technical assistance, improvements in the infrastructure, etc. the investors are motivated to invest in the businesses within the industrial zones. As a result, these zones could be considered as the representatives of the local economic development and the economic reforms. Eugenia et.al 2013 also mention the role of EPZs. According to them, their role is to support a country in the process of achieving local development. The contribution of the industrial park in this is measured by the number of jobs generated, by the income earned by the government through the taxes and duties paid by the industries and firms operating within the zones, and also according to the development of infrastructure facilities by the local institutions to attract foreign investments.

According to Engman et.al 2007, most of the developing countries in the world have been using EPZs as their passage for industrialization as they provide so many benefits to a country. The EPZs can generate more and more economic opportunities and ultimately generate many throughputs for a country. Among them, one of the most important is the generation of employment opportunities. Many employment opportunities were generated by the EPZs nearly 38.2 million which represents $0.2 \%$ of the global employment by the time of 2003. As they mention the reason for many of the developing countries to establish EPZs within their countries is that their contribution towards attracting foreign direct investments. The countries with a lack of investors try to promote the establishment of the EPZS within their boundaries to promote the provision of funds for their industries. Others who are with good access to the funds but the investments are restricted due to the strict laws and regulations presented by the government.

Asian context: During the 18th and 19th centuries, Western world went through the process of industrialization and achieved rapid economic development. By the time the impacts of industrialization spread to the developing countries and they were able to achieve a great degree of economic development. According to Knivila 2007 the countries like the Republic of Korea (Korea), Taiwan Province of China (Taiwan), and Indonesia have achieved their economic development mainly through industrial development. And she further states that most of the developing countries started to engage and gain rapid development in the economic sector since the 1960s. "Some regions and countries, notably in East Asia, are rapidly catching up to industrialized countries" (Knivila, 2007). The process of industrialization always had a huge impact on the entire world. At the beginning of industrialization, most industries were located in the city centers considering the easiness to procure the raw materials and the other necessities for the production like cheap labor, transportation facilities, logistic facilities, etc. But this development was only limited to the city centers and the peripheral areas had to face huge backwardness due to the process of industrialization. Unlike in the Western world, this problem was severe for developing third-world countries.

Most of the industrial activities of the developing countries were concentrated in the metropolitan regions. As a result, the rural regions of the country had to face many problems in development due to the migration of the labor force, exploitation of resources, etc. "Some countries have managed to achieve growth with equity, whereas in others inequality has remained high. The main emphasis is on describing their growth processes and strategies, the role of industrial development, the contribution of a range of policies to growth performance, and the impact of growth on poverty and income inequality" (Knivila,2007). To overcome the problems caused by economic disparities the central institutions of the developing countries have decentralized the industrial activities. The main objective of the decentralization of the industries to the rural regions is to achieve uniform development in every region and to develop strong economic linkages between rural-urban regions. "Decentralization of industries connotes industrial redistribution or diffusion of industries from core city area to its outskirts. The main objective of this strategy is uniform regional development with the establishment of a strong linkage between rural and urban economy" (Roy, 2016).

The developing countries were widely adopting the concept of EPZs or the Special Economic Zones to attract foreign investments and to promote import-export industries. With the establishment of the EPZs within the developing countries, these countries have been able to achieve rapid growth in the economy, also the huge disparity among the rural and urban regions has been reduced. According to Jha and Jha (2012), these EPZs or the Special Economic Zones could be identified as a way of reducing the disparities among the rural and urban regions and achieving balanced regional development. "The center has an important role to play in promoting balanced development in which all states and regions within the states have an opportunity to develop equally. The central government, to reduce regional disparities, thought that these SEZs could be a good tool to reduce the disparities. That is why one of the objectives of SEZs is to achieve balanced regional development" (Jha et.al, 2012). They further define EPZs or Special Economic Zone as a geographical region concentrated with production or export-import activities, which are, governed by special economic laws. These areas provide the investors with special tax and tariff reliefs to promote and create a favorable environment for the investments. According to Jha, there are few major objectives of EPZs. Raising economic growth is the major objective of the establishment of EPZs within developing countries. They further try to attract more Foreign Direct Investments for the promotion of industrial activities and to stimulate the inflow of advanced technologies to the country. Another important objective is the promotion of exports. With the expansion of industries, the developing countries could increase production and engage in the 
global market. And with the expansion of industries requirement for labor and good quality infrastructure facilities is also increasing. Hence generation of more employment opportunities and increasing the availability of good quality infrastructure facilities is another important objective of EPZs.

According to Cho (2012), industrial parks located in Korea and their contribution to the development Industrial parks are the main contributors to the economic development in Korea. The economic development of the Republic of Korea mainly depends on the manufacturing sector and the industrial parks have a significant impact on the economic and manufacturing sector development. In the 1970's they have established industrial parks to promote national economic growth. Since the 1980's the purpose of establishing industrial parks was to achieve balanced national development and to reduce rural-urban disparities. From the 1990s hightech industrial parks were located to achieve the advancement of the industrial sector. In 2000 the industrial parks were located to diversify the industrial structure and to obtain a considerable place in the global market. The Korean condition of industrial parks is somewhat different from the other developing countries. They developed the industrial parks within the country along with the agricultural sector. "There have been remarkable achievements made by industrial parks as main axes and growth engines for remarkable economic growth and development of the nation. Manufacturing businesses of industrial parks accounted for only $3 \%$ of the nation's manufacturing sector in the 1970s, but the percentage grew to $12.4 \%$ in the 1990 s. The number of workers of manufacturing businesses of industrial parks accounted for $2.3 \%$ of the total workers of the manufacturing sector in the 1970s, but it grew more than ten times to $27.8 \%$ in $1990 "$ (Cho, 2012).

EPZs are the most successful mechanism used by most developing countries especially East Asian countries to promote the process of industrialization. The main purpose of Table 1: Export Processing Zones located in Sri Lanka

\begin{tabular}{lrr}
\hline Location & No of enterprises & Year of establishment \\
\hline Katunayake EPZ & 86 & 1978 \\
Biyagama EPZ & 58 & 1985 \\
Koggala EPZ & 20 & 1991 \\
Kandy Industrial Park & 21 & 1994 \\
Wathupitiwala EPZ & 17 & 1998 \\
Mirigama EPZ & 6 & 1998 \\
Malwatta EPZ & 4 & 1998 \\
Seethawake EPZ & 30 & 1999 \\
Horana EPZ & 12 & 1999 \\
Mawathagama EPZ & 7 & 2000 \\
Polgahawela EPZ & 5 & 2000 \\
\hline Total & $\mathbf{2 6 9}$ & \\
\hline
\end{tabular}

Source: Impacts of EPZs on poverty reduction and trade facilitation in Sri Lanka -2013

By establishing EPZs within the rural areas the government target promoting the development of infrastructure facilities and upgrading of industrial activities within such areas to enhance regional development. The poor with low skill levels living in the rural areas get more employment opportunities which help in alleviating poverty. Engaging in international trade is the key to achieve economic growth and poverty reduction in developing countries. Therefore, for implementing Special Economic Zones within the country is to attract Foreign Direct Investments (FDI) especially for the development of the manufacturing sector, creation of employment opportunities, engage in the export sector and attract foreign income into the country, and so on. (Zeng, 2015). Special Economic Zones or the EPZs are established to achieve a certain set of objectives. "Economists also believe that SEZs can achieve industrial development more efficiently and effectively. In particular, investing in SEZs can: 1) Provide a bundling of public services in a geographically concentrated area; 2 ) Improve the efficiency of limited government funding/budget for infrastructure; 3) Facilitate cluster development, or agglomeration of certain industries, and 4) Propel urban development - providing conducive living conditions for workers and for diaspora science and technical personnel, and conglomeration of services, including obtaining economies of scale for environmental services such as water treatment plants and solid waste treatment plants" (Zeng,2015). Therefore, the creation of employment opportunities and income generation and promoting ecofriendly cities can be considered as the uses of EPZ or SEZ. (Lin et.al, 2014).

Sri Lankan context: When considering the Sri Lankan situation of development, the country was depending on hydroagricultural economic activities in the past. With the starting of the open economy, the main concentration of the government was on industrial development. All the industries were concentrated in the metropolitan regions in the country considering the availability of facilities. As a result of this other rural regions of the country was lacking in development for many reasons. Considering all those factors the central institution of the country has initiated EPZs within different rural areas away from metropolitan regions in the country.

countries like Sri Lanka the best option to overcome such issues is the establishment of EPZ. "While Sri Lanka initiated the process of trade liberalization in South Asia, other barriers such as administrative and technical barriers have become an increasingly significant impediment to trade. To promote export competitiveness in Sri Lanka, it is essential to remove such barriers. One way of doing so, and thereby facilitate trade, is through EPZs that provide customs-free and tax-exempt, export-oriented manufacturing facilities, 
investment incentives and streamlined administration, cheap utilities, and better infrastructure. Trade facilitation may be the quintessential purpose of these zones, but another important aspect of EPZs is their potential to alleviate poverty" (Karunaratne et.al, 2013).

The EPZs within Sri Lanka have been playing a very important role in the economic development of the country. The zones have been playing a significant role in the production expansion of manufacturing goods. In 1980 the total industrial exports generated by the zones was only $8.8 \%$, whereas by 1991 it has risen to $44 \%$. By 2007 the share was 38\%. (Abewardhana et al, 1994 and Boyange, 2007). There is a significant contribution for the employment generation as well. When considering the contribution of the EPZs to poverty reduction direct employment generation can be considered as the most significant factor. According to the Department of Census and Statistics 2012 report, EPZs in Sri Lanka consists of nearly $83 \%$ of low-skilled labor in the manufacturing sector. The availability of employment opportunities for females is another important contribution to poverty reduction. "Of the 12 economic zones in the country, 10 have a higher proportion of females than males. In many of these zones, there is a substantially higher share of women workers. For example, in the Koggala EPZ, which employs more than 11,500 workers, 74 percent of the workforce comprises females, while in the Wathupitiwala EPZ and Kandy IP, which employ roughly 8,200 and 6,900 workers, respectively, the proportion of female workers in both zones is 73 percent. The Mirijjawila IP, which totals more than 1,400 workers, features a workforce that is 91 percent female." (Karunaratne et.al, 2013). And also another important factor is that the generation of indirect employment opportunities for the people living in the areas surrounding the zone. "Hostels, restaurants, and other business ventures have arisen around EPZs to cater to the employees that work in these zones. Many of these workers originally come from towns and villages that are located far away from the zone in which they work. These services are provided by entrepreneurs who startup businesses around the zones, contributing to what is termed tertiary employment. Secondary employment is generated through services that are offered directly to the companies operating within these zones. These services are provided by firms such as freight forwarders and logistics providers, which offer transportation, delivery and shipping services to the manufacturers as well as recruitment agencies that supply the manufacturing firms with human capital" (Karunaratne et.al, 2013).

According to the research done by Waniganeththi based on Wathupitiwala EPZ (1999) in Aththanagalla Divisional Secretariat, the zone has a significant contribution to the regional development of the area. According to the report, the main objective of the establishment of the EPZs within the country was to increase the regional development in the country. "Exports Processing Zones which were introduced under the open economic policy in 1977 plays the most significant role with related to the regional development in Sri Lanka" (Waniganeththi, 2010). With the establishment of the zone number of positive changes have been occurring within the region. "Infrastructure facilities such as transportation, electricity, telecommunication, banks developed via the established Wathupitiwala EPZ. Generated direct and indirect employment opportunities. Income and expenditure of the local community have changed, while their savings and investments increased in addition to the direct investments in the project. Developed Health and Education facilities." (Wani- ganeththi, 2010). According to Waniganeththi, the contribution of EPZ for the development of employment opportunities, upgrade the living standards of people in the area, increase the infrastructure facilities, and ultimately for the development of the entire region. "A rapid development has been taken place in Wathupitiwala and Aththanagalla Divisional Secretariat after the establishment of EPZ. Employment opportunities of the region have risen because the zone generates many direct and indirect employment opportunities. As a result of that income level and savings of the people have improved. The value of land in the density areas of the processing zone has gone up after 1999. Education, power and electricity, health care and sanitation, road network, and telecommunication have significantly developed through that it has contributed to the development of the region. Comparatively, it has supported to uplift the living standard of the people" (Waniganeththi, 2010).

Since the establishment of the EPZs has a huge impact on the development of various aspects of the regional development various geographical and economic theories have been used to identify their exact contribution to the development. Shift Share analysis is one of the theories used by most researchers to prove their contribution to the employment growth in the regions. Shift Share analysis helps to identify the growth and decline of the number of employment opportunities in a particular industry. It has three components as National Growth, Industrial Mix, and Regional Share. "The Shift Share technique has three components, namely: national growth, proportionality shift (also known as industrial mix, composition effect or structural effect), and differential shift (also known as a regional share, competitive effect, or local-factor effect) to explain the disparity between regional and national growth." (Rosendo et.al., 2007). Rosendo and Edmundo have researched the Philippines to identify the regional employment growth and have identified the periods of positive growth and negative growth. In Philippines, some of the regions are developing faster than other regions. Their development mainly depends on the performances of the leading sectors within the country and their performance mainly depends on the employment generation.

According to Roy, both primary and secondary data have been collected. The primary data have been generated from different questionnaire-based survey interacting target groups. And the secondary data for the study has been collected by referring to various government and non-government publications. "To reveal the real scenario of decentralization both primary and secondary data have been collected. The primary data have been generated from different questionnaire-based surveys interacting with two target groups; one is the managerial section of different large companies and the other is the proprietor of Micro, Small, and Medium Scale Enterprises (MSMEs). The secondary data were extracted from different sources of government and non-government publications." (Roy, 2016). Waniganeththi 2010 has used simple random sampling for the sample selection. For the collection of data questionnaires, interviews, and observation methods have been utilized. "The methodology was random sampling and data were collected through questionnaires, interviews, and observations."(Waniganeththi, 2010).

\section{MATERIALS AND METHODS}

Sampling and data collection: Data are the collected information and they can be used by the researchers to fulfill the 
objectives of the research. Mainly there are two types of data;

- Primary data

- Secondary data

Secondary data: Secondary data are the data that have been stored in books, newspapers, reports, journals, research articles, etc. These data can be used by many people other than the person who has collected the data. The data are taken from the Board of Investment, Department of census and statistics, Sampath Pathikada from Biyagama Divisional Secretariat were the sources that have been used for the collection of secondary data.

Primary data: Primary data are the information that has been collected directly from the source. The parties who gather primary data may be an authorized organization or a person to make a particular study a success. These primary data could be collected through the following methods;

- Questionnaire surveys

- Interviews

- Direct observations

Questionnaire - A structured questionnaire has been used by the researcher to get information from the respondents. The questionnaire survey has been conducted within the month of January. This questionnaire survey has been used to collect primary data to identify the influence of the EPZ on the generation of indirect employment opportunities for the people of the area.

Interviews - interviews have been conducted with the officials from the regional engineering office of the Electricity Board and Water Board in Kadawatha, Officials from the Board of Investment, etc.

Direct observations - The observation method has been utilized to observe the visible social and physical development aspects of the area.

Sample: Biyagama Divisional Secretariat is divided into 49 GN divisions. Out of those GN divisions, 100 people Walgama West GN division have been selected using a random sampling method. The study selected the GN division purposively considering the proximity to the BEPZ and 100 villagers have been selected randomly.

\section{Analytical Techniques}

Shift Share Analysis: The analysis mainly compares the employment growth of a particular region with the employment growth of the entire nation. The method attempts to determine the regional employment growth or decline with relation to national, industrial, and regional factors. It can be divided the employment growth of a particular industry into three main components. They are;

- National Share Effect

- Industrial Mix Effect

- Regional Competitiveness Effect

National Share Effect - National Share Effect explains the development of job growth of a particular industry concerning the entire nation. It calculates the impact of the regional employment growth on the entire nation.

$$
N S_{i}=e_{i, t-1} * \frac{E_{t}-E_{t-1}}{E_{t-1}}
$$

$\mathrm{NSi}$ - Change of employment due to the national trends ei,t-1 - Employment in the industry in the region in a particular industry in the first year

Et - Total national employment in all industries in the most recent year

Et-1 - Total national employment in all industries in the first year

- Industrial Mix effect - Estimates the employment growth or decline of each industry due to the changes in the industry and total national growth rates.

$$
I M_{i}=e_{i, t-1} *\left(\left(\frac{E_{i, t}-E_{i, t-1}}{E_{i, t-1}}-\frac{E_{t}-E_{t-1}}{E_{t-1}}\right)\right)
$$

IMi - Change in employment due to industrial mix

e i,t-1 - Employment in the region in a particular industry in the first year

$\mathrm{E} \mathrm{i}, \mathrm{t}$ - Total national employment in that industry in the most recent year

E i,t-1-Total national employment in that industry in the first year

Et - Total national employment in the most recent year

Et-1 - Total national employment in the first year

- Regional Competitiveness Effect - calculates the employment growth or decline that occurred as a result of the region's competitiveness.

RSi - Change in employment due to National Shift

e i,t-1 - Employment in the industry in the region in a particular industry in the first year

e i,t-1 - Employment in the region in a particular industry in the first year

e i,t - Total regional employment in a particular industry in the most recent year

$\mathrm{E} \mathrm{i}, \mathrm{t} \quad$ - Total national employment in a particular industry in the most recent year

E i,t-1 - Total national employment in a particular industry in the first year

$$
R S_{i}=e_{i, t-1} *\left(\frac{e_{i, t}-e_{i, t-1}}{e_{i, t-1}}-\frac{E_{i, t-1}-E_{i, t-1}}{E_{i, t-1}}\right)
$$

The Shift Share analysis will be utilized in this study to examine the contribution of the BEPZ for the growth or the decline of the direct employment opportunities within the region.

Map Analysis: Map analysis techniques will be used for examining the settlement expansion to understand how the number of settlements has increased with the establishment of the BEPZ by comparing the number of settlements within 100m, 200m, and 300m

\section{RESULTS AND DISCUSSION}

\section{Contribution of BEPZ for Regional Development}

Socio-economic profile of the sample: According to Figure 1 , the number of male respondents engaged in employment is higher than the female respondents. 
Figure 1: Occupation according to the gender

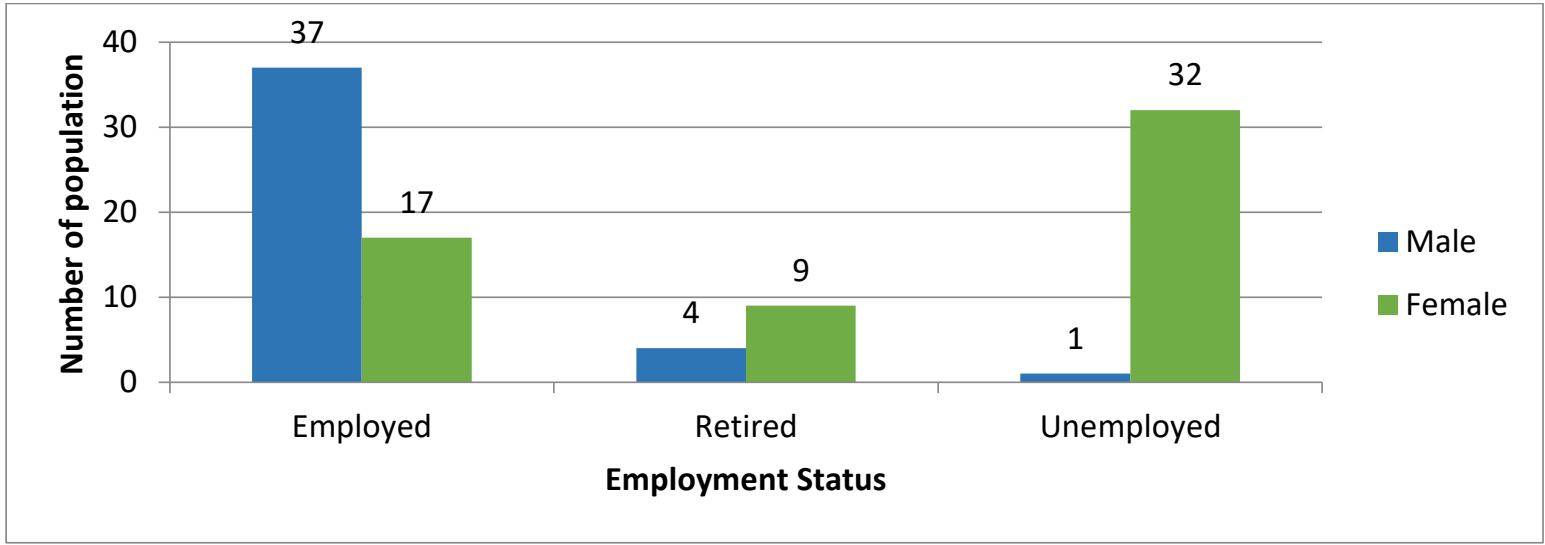

Source: Source: Sample Survey, 2018

According to Figure 2, most of the male respondents are engaged in employment within EPZ. Very few and equal

\section{Figure 2: Sector of employment according to gender}

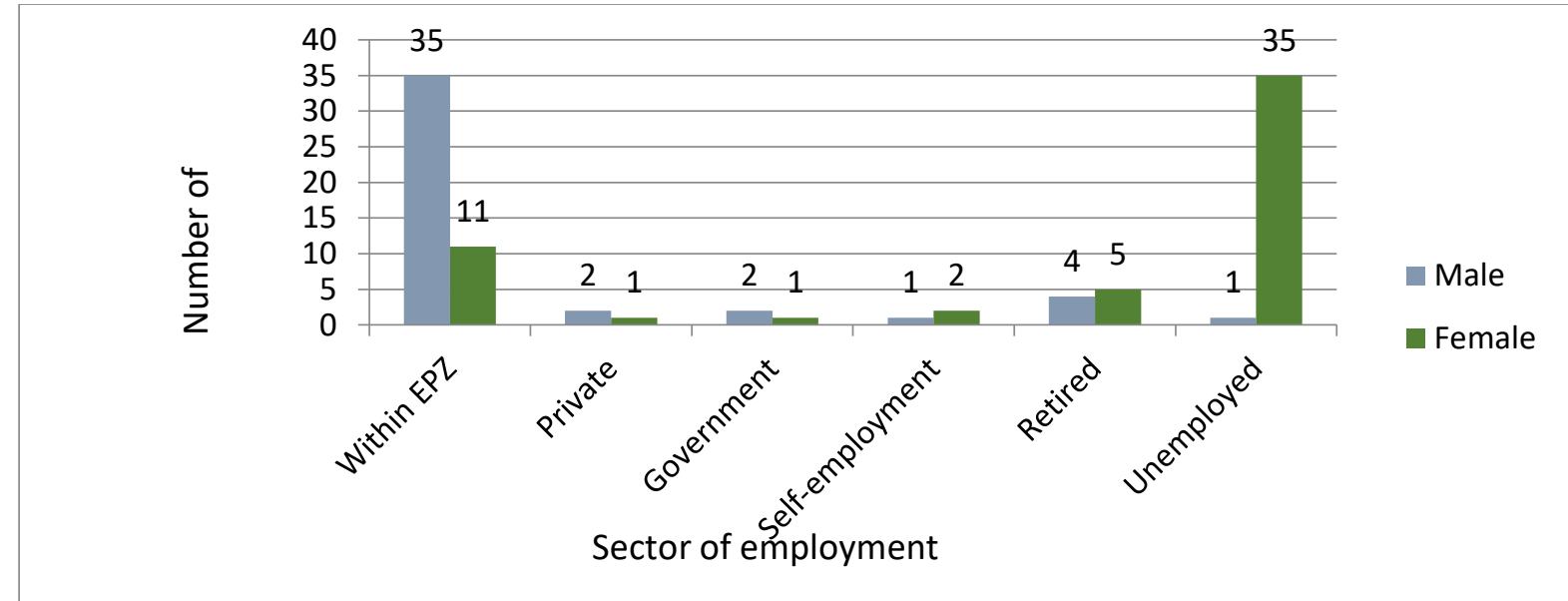

amounts of respondents are engaged in government, private, and self-employment sectors. Most of the female respondents are unemployed.

Source: Sample Survey, 2018

According to Figure 3, the majority of the respondents engaged in indirect employment opportunities are associated with the EPZ.

Figure 3: Involvement in indirect employment activities

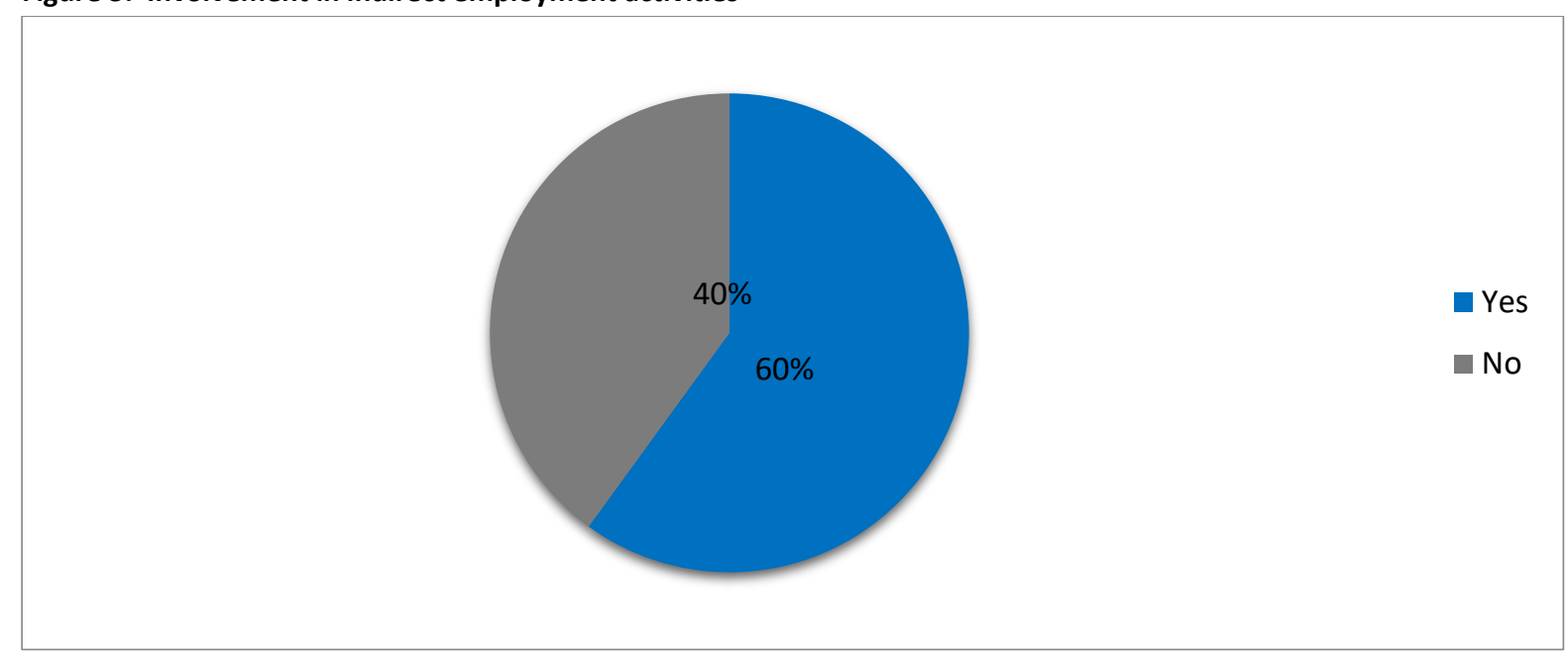

Source - Sample Survey, 2018

Figure 4 illustrates the types of other income activities re-

the respondents provide boarding facilities for the employspondents engage in for earning extra income. Majority of ees of the EPZ as a way of earning extra income. The second largest other income-earning activity is operating shops. 
Figure 4: Types of indirect employment activities

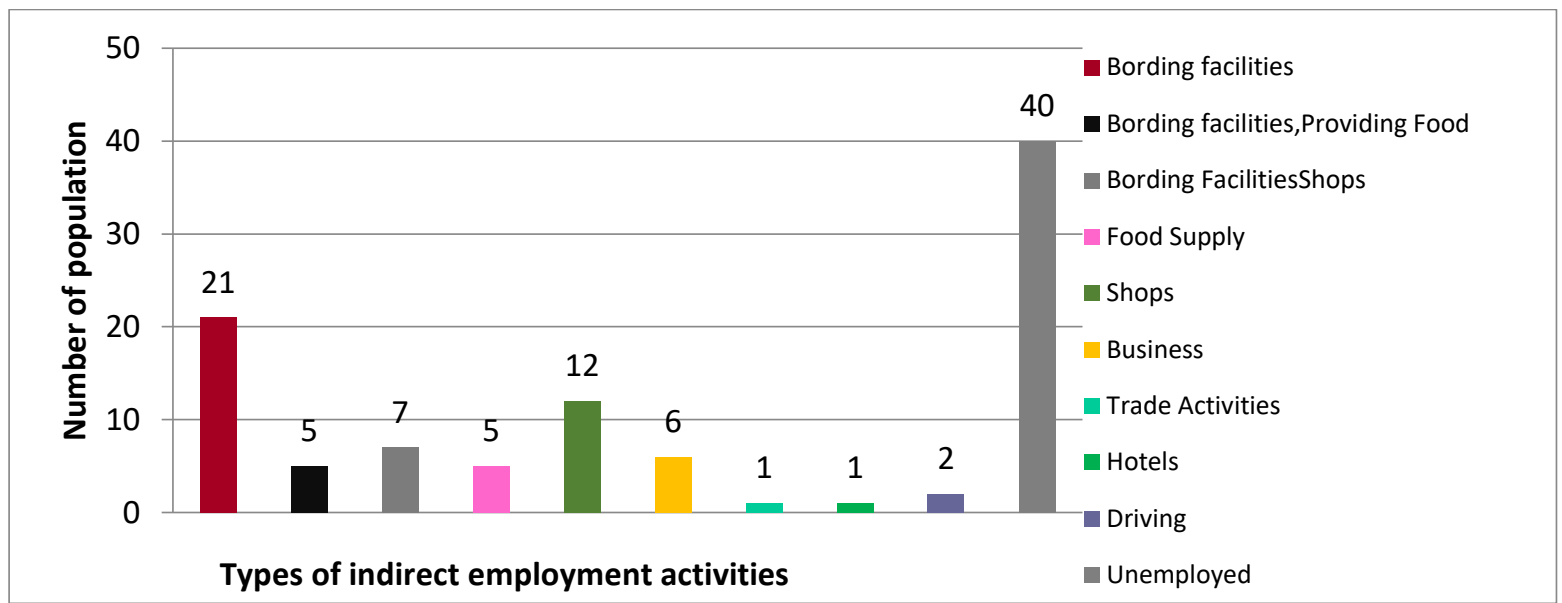

Source: Sample Survey, 2018

All the respondents have agreed that the living standards of the people in the area have risen as a result of the EPZ. With the establishment of the EPZ number of direct and indirect employment opportunities have been emerged for the peoFigure 5: Rising standards of life

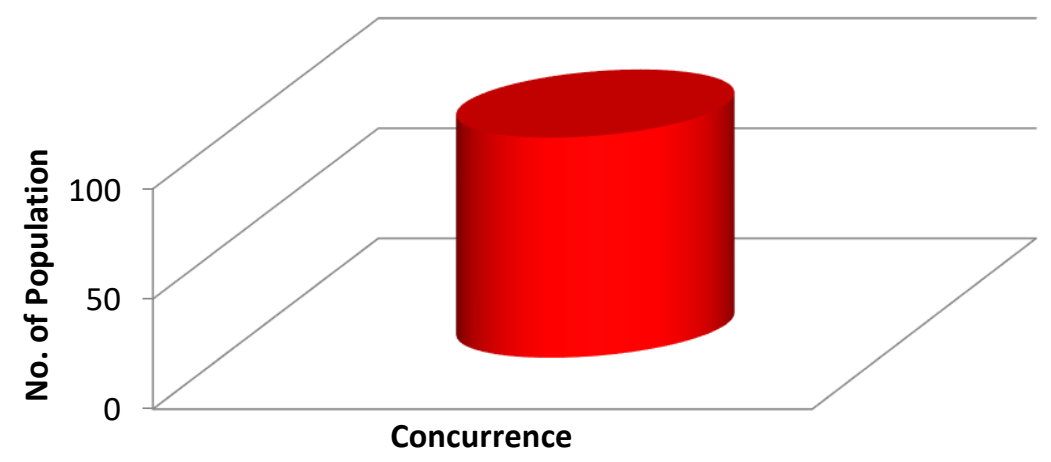

Source: Sample Survey, 2018

Physical development of Biyagama DSD

The physical development of the area with the establish-

infrastructure facilities, generation of employment opportument of the EPZ is displayed within the development of the

Figure 6: Physical development

Sample

Survey,

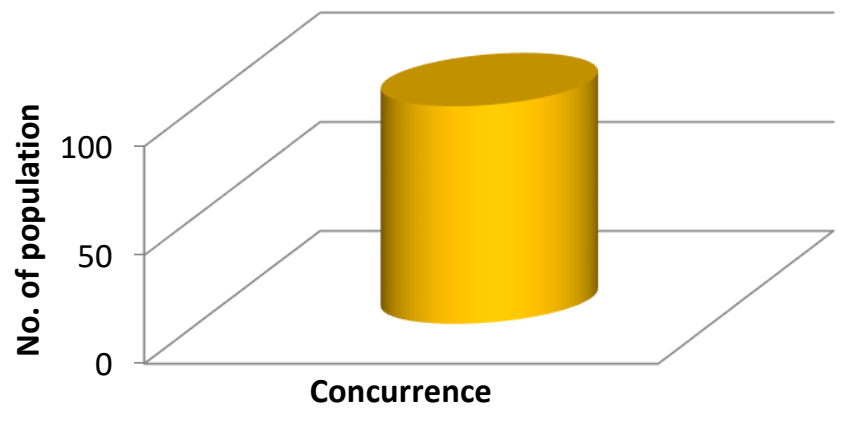

infrastructure development

Source: Sample Survey, 2018

As illustrates in Figure 6, All the respondents have agreed that the physical aspects of the area have been developed with the establishment of the EPZ. As the respondents stated the government has taken various attempts for the development of the road networks, provision of electricity and water facilities, providing educational and health facilities, etc.

Expansion of settlements through time has been analyzed using map analysis methods. Buffer zones have been created for analyzing the expansion of the settlements. 
Map 1, 2, 3 and 4: Settlement expansion in the years of 1981, 2005, 2010 and 2018
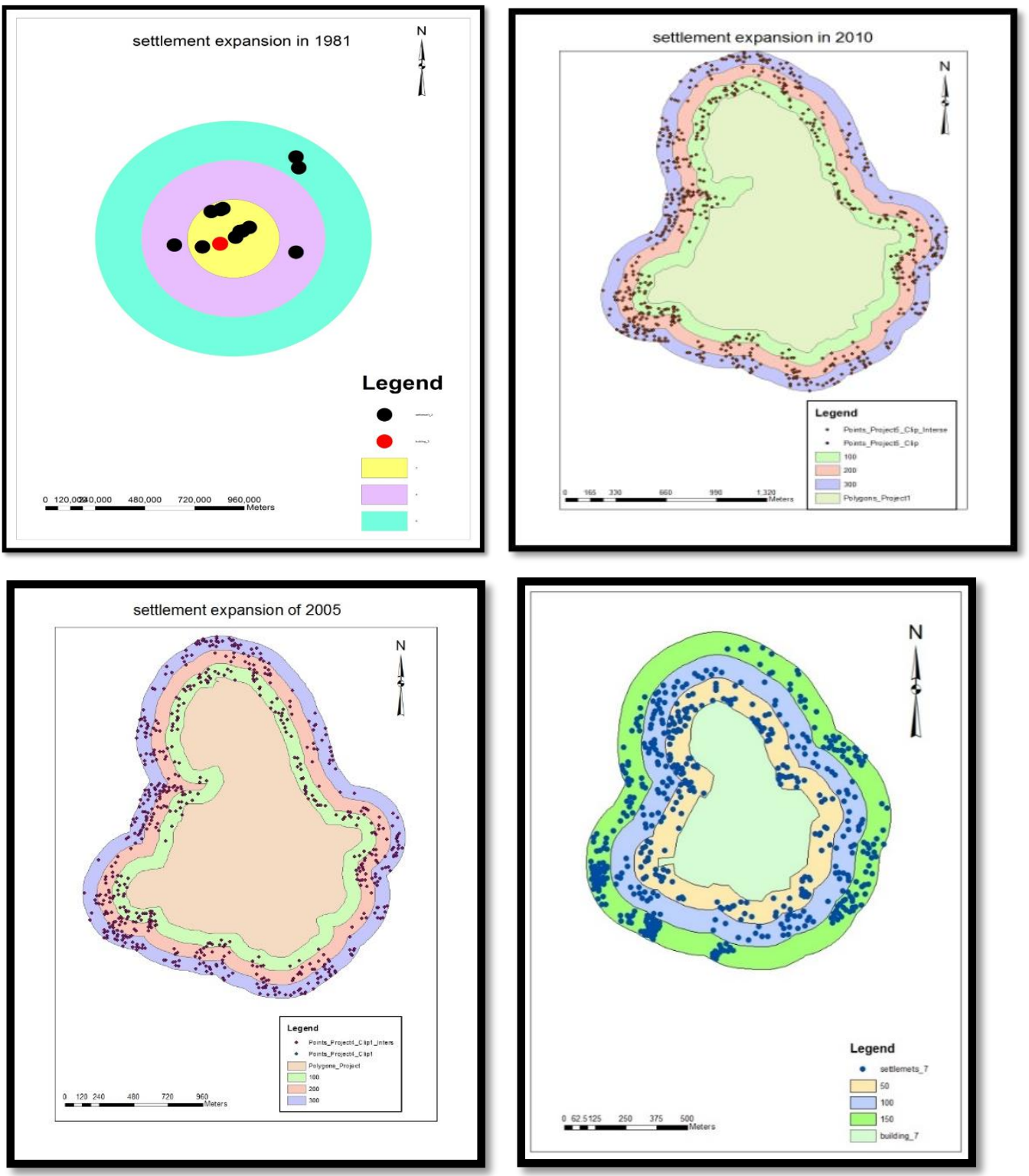

Source: Google Earth Pro, 1981, 2005, 2010 and 2018

According to the information represented by using the maps for the years of 1981, 2005, 2010, and 2018, expansion of the settlements could be identified clearly. In 2005 the number of settlements in Biyagama Divisional Secretariat was nearly 633. The distribution of these settlements has been displayed in the buffer map as well. By the year 2010, the

number of settlements has been increased up to 746 . By the year 2018, the total number of settlements has been increased up to 1909. The increase of the settlements has been displayed using the buffer maps as well. According to the graph, the number of settlements in the area has been increased by 1276 from 2005 to 2018.

Figure 7: Expansion of the settlements

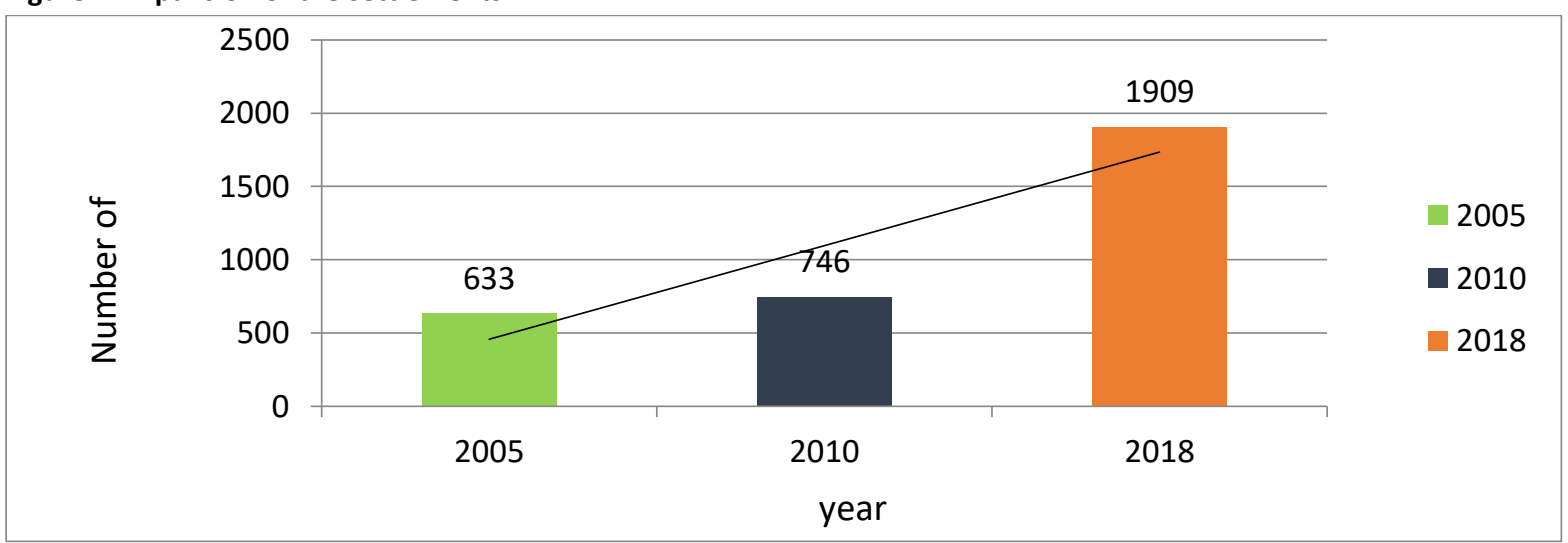




\section{Shift Share Analysis}

Shift Share analysis is a regional analysis that can be utilized to examine the change that occurred in the employment generation due to the national changes and unique regional factors. According to the Shift Share Analysis employment growth or decline mainly depends on three components.
National Growth effect (NGE): The National Growth Effect (NGE) is the employment growth or decline that happens within the region due to the total change in employment within the entire nation. According to the study, the employment of the region has changed due to the national employment change.

Table 2: Employment by sector in BEPZ

\begin{tabular}{lrrrr}
\hline Industry Sector & \multicolumn{3}{c}{ Total Employment of by sector in Biyagama } \\
\cline { 2 - 5 } & 2005 & 2015 & $\begin{array}{c}\text { Change in } \\
\text { Number }\end{array}$ & $\%$ of change \\
\hline Food Beverage and tobacco & & 1597 & -394 & $-20 \%$ \\
Textile wearing apparel and tobacco & 1991 & 14202 & 5170 & $57 \%$ \\
Paper products printing and publishing & 9032 & 748 & 747 & $74700 \%$ \\
Paper products printing and publishing & 1 & 748 & 747 & $74700 \%$ \\
Chemical petroleum rubber and plastic & 1 & 5301 & 1009 & $24 \%$ \\
Non-metallic mineral products & 4292 & 864 & -742 & $46 \%$ \\
Metal products, machinery, and equipment & 1606 & 295 & 244 & $24 \%$ \\
Other manufacturing & 51 & 3180 & -779 & $478 \%$ \\
Total & 3959 & 26187 & 5255 & $25 \%$ \\
\hline
\end{tabular}

Source: BOI progress report, employment data for 2005 and 2015

Table 3: Employment by sector in Sri Lanka.

\begin{tabular}{lrrrr}
\hline Industry Sector & \multicolumn{3}{l}{ Total Employment of by sector in Sri Lanka } \\
\cline { 2 - 5 } & 2005 & 2015 & $\begin{array}{r}\text { Change in } \\
\text { Number }\end{array}$ & $\%$ of change \\
\hline Food Beverage and tobacco & & 226,851 & 45,675 & $25 \%$ \\
Textile wearing apparel and tobacco & 181,176 & 61,334 & $13 \%$ \\
Paper products printing and publishing & 467,802 & 529,136 & 8,405 & $31 \%$ \\
Chemical petroleum rubber and plastic & 26,749 & 35,151 & 5,630 & $8 \%$ \\
Metal products, machinery, and equipment & 74,772 & 80,402 & $-11,465$ & $-63 \%$ \\
Other manufacturing & 18,295 & 6,830 & $-16,458$ & $13 \%$ \\
Total & 127,192 & 110,734 & 52,306 & $5 \%$ \\
\hline
\end{tabular}

Source: Department of census and statistics, industrial progress report 2005, 2015

According to the above Table 2 and 3 employment has changed in both national and regional contexts. There has been a positive change in some industries and there has been a negative change for some of the industries. Considering the total change that happened in employment from

Table 4: National Share

\begin{tabular}{|c|c|c|}
\hline Industrial sector & Equation & National share \\
\hline Food beverages and tobacco industry & 1991*(1 018 931-966 628) / 966628 & 108 \\
\hline Textile wearing apparel and leather & $9032 *(1018$ 931-966 628) / 966628 & 489 \\
\hline Paper products printing and publishing & $1 *(1018931-966$ 628) / 966628 & 0 \\
\hline Chemical petroleum rubber and plastic & $4292 *(1018931-966$ 628) / 966628 & 232 \\
\hline Non-metallic mineral product & $1606 *(1018$ 931-966 628) / 966628 & 87 \\
\hline $\begin{array}{l}\text { Metal products machinery and equip- } \\
\text { ments }\end{array}$ & 51*(1 $018931-966$ 628) / 966628 & 3 \\
\hline \multirow[t]{2}{*}{ Other manufacturing } & 3959*(1 018 931-966 628) / 966628 & 214 \\
\hline & & 1133 \\
\hline
\end{tabular}

Source: Calculated by the author

According to Table 4 , if the industries in the BEPZ have been affected by the national employment change of $5 \%$;

- The food beverages and tobacco industry are expected to have a growth or decline of 108 employees.
2005 to 2015 the national employment has changed by $25 \%$. But national employment has changed by only $5 \%$. NGE is the possible employment change that can occur when all the industries operating within the zone are being affected by the national change of $5 \%$. 
- Paper products printing and publishing industries were not located within the zone in 2005 . Hence the expected employment change is zero.

- The Chemical petroleum rubber and plastic industry are expected to have a growth or loss of 232 employees

- Metal products machinery and equipment industry are expected to have a growth or loss of 3 employees.

Table 5: Employment Change due to NGE
- Other manufacturing industries are expected to have a growth or loss of 214 employees.

Collectively, all the industries are expected to have a change of 1133 employment opportunities. But in actual context, the BEPZ has achieved a change of 5255 employment opportunities.

Achieved change in employment

Expected change in the employment

Source: Calculated by the author

According to the findings of NGE, there has been a 4122 growth of employment.

Industrial Mix effect: The industrial sector of a country consists of many industries. By the time there may be a growth or decline in the employment within these industrial sectors.
The industrial mix effect calculates the change of employment that happens in each industry within the region as a result of the employment change happen in each industry in the nation. In other words, it calculates how the national change in employment in a particular industry affects the employment in the industries operating within the zone.

Table 6: Industrial Mix Effect

\begin{tabular}{|c|c|c|}
\hline Industrial sector & Equation & $\begin{array}{r}\text { Industrial Mix } \\
\text { Effect }\end{array}$ \\
\hline $\begin{array}{l}\text { Food beverages and tobacco in- } \\
\text { dustry }\end{array}$ & $\begin{array}{l}1991 *(((225,851-181,176) / 181,176)-((1018931-966628) / / \\
966628))\end{array}$ & 394.21 \\
\hline $\begin{array}{l}\text { Textile wearing apparel and } \\
\text { leather }\end{array}$ & $\begin{array}{l}9032 *(((529,136-467,802) / 467,802)-((1018931-966628) / \\
966628))\end{array}$ & 695.48 \\
\hline $\begin{array}{l}\text { Paper products printing and pub- } \\
\text { lishing }\end{array}$ & $1 *(((35151-26749) / 26749)-((1018$ 931-966 628) / 966 628)) & 0.26 \\
\hline $\begin{array}{l}\text { Chemical petroleum rubber and } \\
\text { plastic }\end{array}$ & $4292 *(((80402-74772) / 74772)-((1018931-966628) / 966$ 628)) & 90.93 \\
\hline Non-metallic mineral product & $1606 *(((29827-70642) / 70642)-((1018931-966628) / 966$ 628)) & $(1,014.80)$ \\
\hline $\begin{array}{l}\text { Metal products machinery and } \\
\text { equipments }\end{array}$ & $51 *(((6830-18295) / 18295)-((1018931-966628) / 966628))$ & $(34.72)$ \\
\hline Other manufacturing & $\begin{array}{l}3959 *(((110734-127192) / 127192)-((1018931-966628) / 966 \\
628))\end{array}$ & $(726.49)$ \\
\hline
\end{tabular}

Source: Calculated by author

According to the above Table 6, the changes in employment of each of the industries within the nation have a negative impact on the employment change within the zone. 3 out of 7 industrial sectors show a decline in their employment change on the national scale. They are;

- Non-metallic mineral products

- Metal products machinery and equipment

- Other manufacturing

Out of these industries, non-metallic products have the highest loss of employment in the nation. One of the possiTable 7: Regional Competitiveness Effect

\begin{tabular}{llr}
\hline Industrial sector & Equation & Regional Share Effect \\
\hline $\begin{array}{l}\text { Food beverages and tobacco } \\
\text { industry }\end{array}$ & $1991^{*}(((1597-1991) / 1991)-((226851-181176) / 181176))$ & -895.94 \\
$\begin{array}{l}\text { Textile wearing apparel and } \\
\text { leather }\end{array}$ & $9032^{*}(((14202-9032) / 9032)-((529136-467802) / 467802))$ & 3985.81 \\
$\begin{array}{l}\text { Paper products printing and } \\
\text { publishing }\end{array}$ & $1^{*}(((748-1) / 748)-((35151-26749) / 26749))$ & 746.69 \\
$\begin{array}{l}\text { Chemical petroleum rubber } \\
\text { and plastic }\end{array}$ & $4292^{*}(((5301-4292) / 4292)-((80402-74772) / 74772))$ & 685.83 \\
$\begin{array}{l}\text { Non-metallic mineral product } \\
\text { Metal products machinery }\end{array}$ & $1606^{*}(((864-1606) / 1606-((29827-70642)) / 70642))$ & 185.90 \\
$\begin{array}{l}\text { and equipments } \\
\text { Other manufacturing }\end{array}$ & $3959^{*}(((295-51) / 51)-((6830-18295) / 18295))$ & 275.96 \\
Total & & -266.75 \\
\hline
\end{tabular}

Source: Calculated by author ble reasons for this loss is the increasing imports of non-metallic mineral products. Collectively, all the industrial sector has a decline of 595 employment opportunities.

Regional Competitiveness Effect: Employment change in the industries within the zone can happen due to the unique changes that occur within the zone itself. Factors like development in the infrastructure facilities, rapidly increasing population within the area can be identified as the factors that contribute to the changes in the employment within the region. 
According to Table 7, the employment within the region has been changed in 4718 as a result of internal factors. There has been a huge change in the employment in the textile, wearing apparel, and leather industry. And also in the paper products, printing, and publishing industry because it has been newly introduced to the region and the employment growth by that industry is a complete gain for the region.

Table 8: Total employment change from 2005-2015
The food beverages and tobacco industry and other manufacturing industries have a negative employment change of -895.94.

Total employment change: Total employment change happened within a particular period within a region equals to a total of National Share, Industrial Mix, and the Regional Competitiveness Effect.

\begin{tabular}{|c|c|c|c|c|}
\hline \multicolumn{5}{|c|}{ Shift Share Analysis } \\
\hline Industrial sector & National Share & Industrial Mix & $\begin{array}{r}\text { Regional Competi- } \\
\text { tiveness Effect }\end{array}$ & $\begin{array}{c}\text { Total employ- } \\
\text { ment change }\end{array}$ \\
\hline Food beverages and tobacco industry & 108 & 394.21 & 895.94 & (394) \\
\hline Textile wearing apparel and leather & 489 & 695.48 & 3985.81 & 5,170 \\
\hline Paper products printing and publishing & 0 & 0.26 & 746.69 & 747 \\
\hline Chemical petroleum rubber and plastic & 232 & 90.93 & 685.83 & 1009 \\
\hline Non-metallic mineral product & 87 & $(1014.80)$ & 185.90 & (742) \\
\hline $\begin{array}{l}\text { Metal products machinery and equip- } \\
\text { ment }\end{array}$ & 3 & 34.72 & 275.96 & 244 \\
\hline Other manufacturing & 214 & (726.49) & $(266.73)$ & (779) \\
\hline Total & 1133 & (595.39) & 3970.84 & 4276 \\
\hline
\end{tabular}

Source: Calculated by the author

According to the above Table 8 , there has been a positive growth of 5255 employment opportunities within the BEPZ. Out of the positive growth of 5255, 1133 employment opportunities were generated as a result of the national changes. There is a negative contribution by the industrial mix effect on the employment change within the region. A decline of 595 employment opportunities can be identified as a result of the industrial mix. The huge decline of employment in the non-metallic mineral product industry and the other manufacturing industries such as the wood and furniture industry, motor vehicles and transport industry, toys industry, logistic service-providing industries, etc can be identified as the result of the decline of employment opportunities occurred within the region. 4717 of employment opportunities have been created by the internal factors within the zone. Out of the total change of 5255 total employment change 4717 employment opportunities were created within the region. Even though there is a positive impact on the employment change within the region there are some industries which record negative growth in the employment such as non-metallic mineral product, Food beverages and tobacco industry, other manufacturing. And the highest contribution for the employment growth comes from the textile wearing apparel and leather industry which is 5170 . According to the results, there is a positive growth of employment Map 5: Available road networks in Biyagama DSD, 2012 in the BEPZ within the period of 2005-2015. The contribution that comes within the region is higher than the contribution from the nation for the employment growth. As a percentage $89.76 \%$ of the total employment growth within the period of 2005-2015 come as a result of the unique changes comes within the region. Hence according to the results, there is a very favorable environment within the region for employment growth.

Infrastructure development: The infrastructure of the area has been developed with the establishment of the zone. At the initial times, the people in the area were engaged mainly in agricultural activities. Hence infrastructure facilities were not much developed in the area. With the establishment of the EPZ, there has been rapid development in the infrastructure sector. For the easiness of analyzing the development of the infrastructure facilities in the area, it has been divided into several sectors.

- Development in the road networks.

- Provision of electricity

- Provision of water facilities

- Availability of the educational facilities

- Availability of Telecommunication facilities

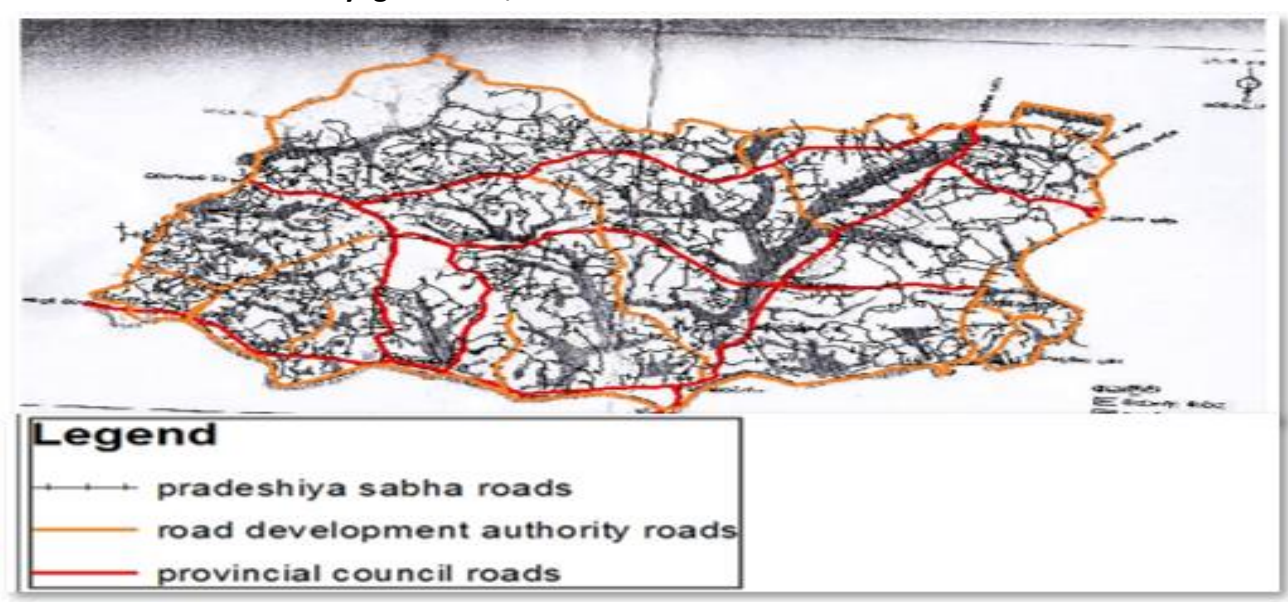

Source: Sampath Pathikada, Biyagama DSD, 2016 
Provision of electricity: According to the information collected from the regional engineering office of the Electricity Board in Kadawatha, all the people in the area are given the power supply. The supply has increased in the year 2013 by 33,444 and by 2014 it has increased by 34,204 consumers. Figure 8: The increasing volume of the electricity consumers from 2014-2018
According to the available data, the consumption of the ordinary power supply has increased rapidly. 365 transformers are operating within the zone providing the power supply of $84.670 \mathrm{KVs}$.

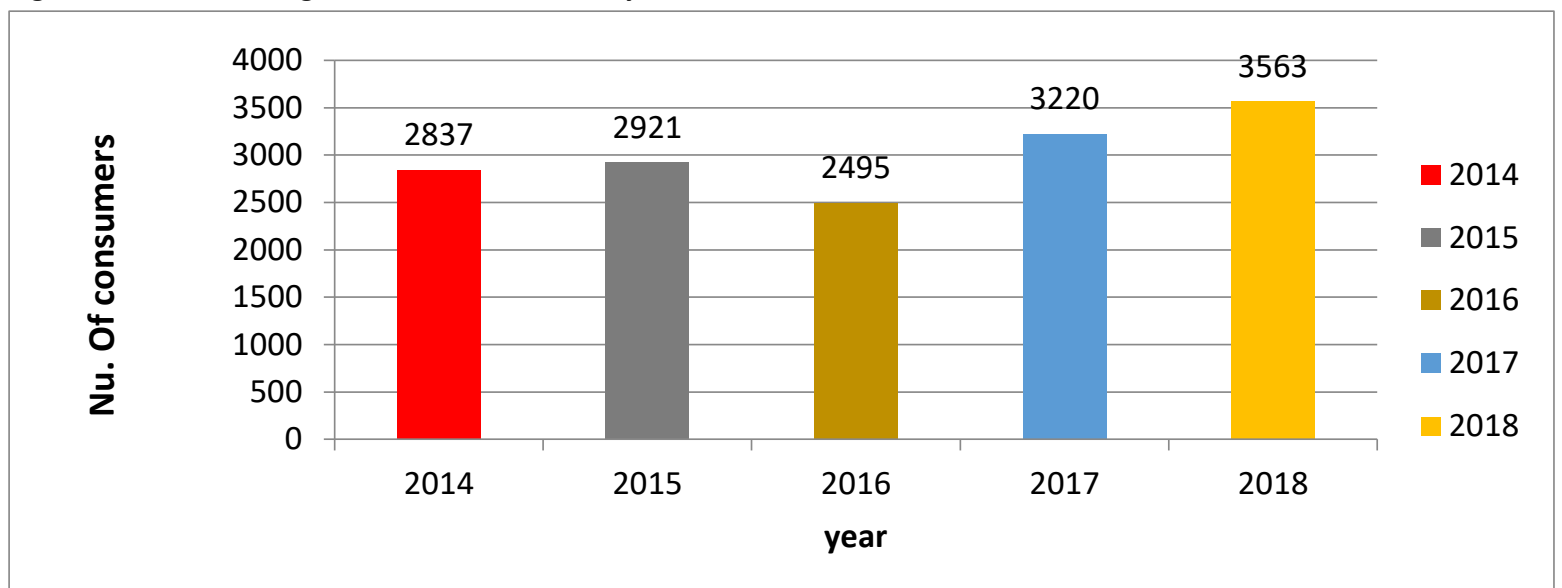

Source: Regional engineering office of electricity board, progress report, 2014-2018

Provision of water: According to the information collected from the regional office of the water board, the water supply for Gampaha District is divided into two sectors. As Biyagama and Mahara Divisions. According to the current data, $98 \%$ of the total water supply is covered by the National Water Supply and Drainage Board. Total water consumers for the year 2014 are 36,395. Due to the increasing water demand comes from the Biyagama division a new project has been implemented in the southern bank of the Kelani River. As a result, the total water supply has increased up to 46099 . The total length of the pipelines of the area is $930 \mathrm{kms}$.

Availability of the educational facilities: The education facilities of the area are also in a good status compared to the past condition of the area. The total count of schools available within the area is 27 . According to the available facilities, the schools available in the area can be divided into four categories. They are;

- Category AB schools - 06

- Category C schools - 05

- Category 2 schools - 07

- Category 3 schools - 09

Availability of Tele - Communication Facilities: There are various telecommunication providers such as Sri Lanka Telecom to provide communication facilities in the area. According to the information available in the Biyagama DSD total number of 10994 of the area has landline supply and 4000 has the wireless supply of Telecommunication.

\section{CONCLUSION}

The study has been conducted to study the contribution of the BEPZ to the development of the Biyagama region. Biyagama region was a very remote area within the country before the establishment of the EPZ. But after 1985 the area has been developed rapidly due to the development of various factors. According to the findings due to the EPZ, some changing factors could be identified within the zone. They are;

- Development in the living standards of the people in the area
- Development of the infrastructure facilities such as road networks, electricity facilities, water facilities, educational facilities telecommunication facilities, etc. and finally,

- The contribution of the EPZ for the employment growth within the region

Before the establishment of the EPZ, the people in the area mainly depended on agriculture-based economic activities. But with the establishment of the zone, most of the people have been engaging in occupation activities within the zone. According to the findings, the majority of the people are engaging in employment within the zone as their permanent income. Other than that, most of the females are engaging in indirect employment activities concerning the EPZ. The majority of them provide boarding facilities within their residences and some of them are operating shops and also some provide food for the employees who are working within the zone. Therefore, the living standards of the people living in the area have risen with the establishment of the Zone. The majority of the females in the area do not engage in direct employment activities. But with the establishment of the zone, they have been allowed to engage in indirect employment activities and achieve some economic power. Gibbon et al in 2008 have also found that with the establishment of the EPZ within a country they crate informal sector employment opportunities reducing the unemployment level. And further confirming the findings of the study, the International Labor Organization in 2008 said that the main objective of the EPZ is to raise people's standard of living and to further economic development. According to Engman et al With the extending amount of employment opportunities the standards of living of the people living in the area is also rising as their income is increasing with the new employment opportunities. Therefore, the rising standards of living, as well as female empowerment, are another important development factor that happened in the study area as a result of the establishment of the zone.

The contribution of the EPZ to the development of infrastructure facilities within the country is another remarkable factor. According to the findings, the zone has a huge impact on the development of infrastructure facilities within the region. Before the establishment of the zone, the area was lacking in proper infrastructure facilities. As the objective of 
the zone is to attract foreign and local-based investments, they make attempts to develop the area and facilitate the investors to promote the investments. Therefore, all the governments which come to power from time to time make attempts to develop the infrastructure within the country. As a result, the infrastructure facilities within the region have increased rapidly. According to the findings of the study, the area has a well-developed road network system facilitating industrial activities. Power and water supply are available for almost all the people within the Biyagama DSD. Further, the educational facilities, health facilities, and also telecommunication facilities of the area have also increased with the establishment of the zone within the region. Waniganeththi in 2010 has conducted research based on Wathupitiwala EPZ and has also found that the zone contributes to the development of the Infrastructure facilities such as transportation, electricity, telecommunication, banks, etc.

The contribution of the EPZ to employment growth is another important factor. BEPZ has a positive contribution towards the employment growth within the region as well. According to the findings of the Shift Share Analysis, there has been a positive growth of employment in the Biyagama region for the period of 2005-2015. A positive change of 5255 employment opportunities has been generated for the period from 2005 to 2015 . Even though there has been a positive change in the employment growth, there are some industries which show negative growth in employment within the region like Food beverages and tobacco industry, Nonmetallic mineral product, and other manufacturing. The government or the Board of Investments can take necessary actions to maximize the contribution of these industries as well. However, the greatest contribution to the employment growth comes from the textile, wearing apparel, and leather industry. With the proper involvement of the government and other relevant authorities, the contribution of the industries could be increased to achieve sustainable economic development.

However, after the establishment of the BEPZ there have been some social issues and environmental issues caused by the people migrating to the region seeking employment opportunities. According to the people in the area, there has been a huge problem of drug addiction and abusive actions in the area due to the migrants. And also due to the rapid growth of population within the area, environmental and water pollution has become a considerable problem in the area. But the contribution of the BEPZ for the regional developments and sustainable economic development is an obvious and clear factor.

Recommendations: The following factors are the recommendations to increase the performances of the industries within the zone and to minimize the adverse impacts of social and environmental issues to achieve not just the development but sustainable regional development.

- The government shall take action to minimize the adverse impacts of the migrants on the area.

- Find factors that affect the industries with the negative growth and take actions to increase their performance.

- Try to identify the well-performing industries and make attempts to strengthen them.

- Make attempts to minimize the environmental problems caused by the industries.

- Increase the involvement of the industries in welfare activities in the area.

\section{REFERENCES}

Amengual M., Milberg W., 2008. Economic development and working conditions in export processing zones: A survey of trends, International Labour Office. - Geneva: ILO, 72.

Amirahmadi H., \& Wu, W. (1995). Export Processing Zones in Asia. Asian Survey, 35(9), 828-849.

Fakir A.N.M.A.et al., (2013) Export diversification role of Export Processing Zones in Bangladesh, ASA University Review, 7(1).

Abeywardene, J., R. de Alwis, A. Jayasena, S. Jayaweera, and T. Sanmugam (1994). "Export Processing Zones in Sri Lanka: Economic impact and social issues", Multinational Enterprises Programme, Working Paper No. 6. International Labour Organization, Geneva

Aggarwal, A. (2005). Performance of Export Processing Zones: A Comparative Analysis of India, Sri Lanka, and Bangladesh. Indian Council for Research on International Economic Relations, New Delhi.

Aye-ay R.M., Prantilla E.B., (2007). A shift-share analysis on regional employment growth in the Philippines, 10th national convention on statistics.

Castells, M., \& Hall, P. (1994). Technopolis of the world: the market of 21st-century industrial complexes, London: Routledge.

Cho, H. (2012). Industrial parks development strategy and management practices. Retrieved from KDI School of Public Policy and Management. Web Site: http://archievers.kdischool.ac.kr>bitstre.

De Alwis, R. (1994). "Proliferation of EPZs in Sri Lanka", Economic Review, 20(4); 9-11.

Domanski B and Gwosdz K., (2010) Multiplier effects in local and regional development. Quaestiones Geographicae 29(2), Adam Mickiewicz university press, Poznan,27-37.

Eugenia M.L., and Georgeta B.N., 2013. "The role of industrial parks in economic development", annuals of faculty of economics, university of Oradea, Faculty of Economics, (1);123-130.

Engman. M., Onodera.O and Pinali. E., (2007) Export Processing Zones: Past and future role in trade and development, Paris, OECD publication.

Jha.S., Jha.S., (2012) Special Economic Zones in India and regional development, The M.S University of Baroda, 5(1), pp 207-217.

Karunaratne. C., Abayasekara A., (2013). Impact of EPZs on poverty reduction and trade facilitation in Sri Lanka, ARTNeT Working Paper Series No. 134, Bangkok, ESCAP. Available at www.artnetontrade.org.

Kiselakova, D and kiselak, A, 2014. "Analysis of macroeconomic factors for the establishment of industrial parks and their effects on regional development; empirical stud from Slovakia." Asian Economic and Financial Review: Faculty of National Economics, University of Economics, vol 4 (9); pp 1220-1236.

Kniivila M.,(2007).Industrial development and economic growth: implications for poverty reduction and income inequality. In industrial development for the 21st century. Sustainable Development perspectives. United Nations publications.

Lin, Justin Yifu, and Y. Wang. 2014. "China-Africa Cooperation in Structural Transformation: Ideas, Opportunities, and Finances", UNUWIDER working paper 2014/046.

Rosendo. M., Prantilla E.B. (2007) A shift-share analysis on regional employment growth in the Philippines, 10th national convention on statistics.

Sumana Roy. (2016). Decentralization of industries and regional development in Haora district of West Bengal. International Journal of Multidisciplinary Research and Modern Education. Volume II, Issue I.

Waniganeththi, W.G. (2010).contribution of Export Processing Zones on Regional Development in Sri Lanka (A case study in Attanagalla Divisional Secretariat Division). Sri Lanka Journal of Humanities and Social Sciences.1(1)

Zeng. D.Z., (2015).Global Experiences with Special Economic Zones: Focus on China and Africa, World Bank, Trade and Competitiveness Global Practice Group. Website: http://econ.worldbank.org. Visited on 26.03.2018. 